\title{
THE INTERNATIONAL LAW COMMISSION REINVENTS ITSELF?
}

\section{Kristina Dangirdas*}

For most of its history, the International Law Commission has been in the business of producing draft articles. Yet, Sean Murphy's coverage ${ }^{1}$ of the Commission's sixty-fifth session reveals that the Commission has decisively turned away from this format. As Jacob Katz Cogan's earlier post observes, ${ }^{2}$ the Commission is demonstrating a new-found preference for outputs that are explicitly non-binding and betray no aspiration to form the basis for multilateral treaties. The Commission's embrace of alternative formats is a promising response to some of the risks and criticisms associated with producing draft articles. But it is also an incomplete response. To ensure that its work continues to be relevant, ambitious, and influential, the Commission must revise its working methods as well as its outputs. In particular, the Commission should develop procedures for engaging with and soliciting input from the non-state actors who are becoming an increasingly important audience for the Commission's work.

During the first half-century of its existence, the Commission occupied itself primarily with producing draft articles that formed the starting point for multilateral negotiations. This process generated some of the most important treaties of the twentieth century, including the Vienna Convention on the Law of Treaties. These treaties in turn shaped the development of customary international law on the topics they covered; many individual articles that were understood as progressive development at the time the Commission adopted them have subsequently been accepted as reflecting customary international law.

But not every set of draft articles proved to be a rousing success. One indicator that the Commission may have produced a dud is the failure of a treaty based on the Commission's work to attract many parties. Several years ago, José E. Alvarez ${ }^{3}$ tallied up the number of ratifications each treaty based on ILC draft articles received within five years of completion and found that eleven of the Commission's twenty-six treaty efforts garnered fewer than forty ratifications. Of course, states may decline to become parties to these treaties for a variety of reasons. Some of these reflect badly on the Commission, but others do not. For example, it could be that states disagreed with the Commission's ideas about how to progressively develop international law, and multilateral negotiations failed to significantly improve on the Commission's work. It could also be that the Commission took on topics that did not merit the time and effort that ratification would require. Some thirty years ago, Tom Franck, Mohamed El Baradei, and Robert Trachtenberg co-authored a study ${ }^{4}$ observing

* Assistant Professor of Law at the University of Michigan Law School and recipient of the 2013 Deák Prize, awarded annually by the American Journal of International Law to honor a younger author who has published a meritorious contribution to international legal scholarship in the Journal.

Originally published online 14 May 2014.

${ }^{1}$ Sean D. Murphy, Immunity Ratione Personae of Foreign Government Officials and Other Topics: The Sixty-Fifth Session of the International Law Commission, 108 AJIL 41 (2014).

2 Jacob Katz Cogan, The Changing Form of the International Law Commission's Work, 108 AJIL UnBound 4 (2014).

3 JosÉ E. AlvarEZ, INTERNATIONAL ORGANIZATIONS AS LAW-MAKERS (2005).

${ }^{4}$ Thomas M. Franck \& Mohamed ElBaradei, The Codification and Progressive Development of International Law: A UNITAR Study of the Role and Use of the International Law Commission, 76 AJIL 630 (1982).

ASIL and Kristina Daugirdas (C) 2014 
that a narrow focus on codification had converted the Commission's agenda into "a veritable What's What of drafting trivia, a parody of the world's urgent agenda."

Treaties with paltry numbers of ratifications can also affect customary international law-by raising questions about whether any of the treaty's provisions reflect customary international law. This "decodifying" effect can be particularly pronounced for provisions that become the subject of fiercely contested negotiations.

One way to avoid the sting of rejection by states as well as any decodifying effect on customary international law is to skip multilateral negotiations and simply allow the Commission's draft articles to stand as a final product. As Professor Cogan describes, ${ }^{5}$ the Commission is increasingly asking the General Assembly to simply "take note" of its draft articles instead of arranging for multilateral negotiations. By taking this approach, the Commission can still influence state practice and the development of customary international law. For example, states may conform their practice to the Commission's draft articles, either because they believe that the articles already reflect customary international law or because they hope that those draft articles will come to reflect customary international law over time.

This solution has its own problems, however. By presenting its draft articles as a final product, the Commission is arguably legislating surreptitiously. That is, the Commission may be inviting harried international lawyers, judges, and arbitrators to assume that its articles codify extant customary international law, even when they include a large dose of progressive development. This is troubling because progressive development involves controversial policy choices. As a body of experts serving in their individual capacity, the Commission lacks legitimacy for making final decisions about how international law ought to change.

In short, regardless of whether they form the starting point for multilateral negotiations, draft articles offer a way for the Commission to make valuable contributions to international treaty and customary law. But they also involve risks for the Commission and for customary international law. These risks may explain why the Commission has turned away from draft articles. Of the nine topics on the Commission's work program for which at least a tentative decision has been made with respect to the form of output, six will involve output other than draft articles. The Commission will likely produce guidelines for three topics (provisional application of treaties, protection of the atmosphere, and probably protection of the environment in relation to armed conflicts). For two additional topics, the Commission is planning to produce draft conclusions (identification of customary international law and subsequent agreements and subsequent practice in relation to the interpretation of treaties). Finally, for its work on most-favored-nation clauses, an ILC study group is producing a report that "might include guidelines or model clauses or, instead, simply analyze state practice regarding the writing of MFN clauses and the interpretation that tribunals have given those various provisions."

These non-treaty formats track key features of the Commission's Guide to Practice on Reservations to Treaties, ${ }^{7}$ adopted in 2011. The Guide suggests that by turning to non-treaty outputs, the Commission can remain ambitious and influential while avoiding some of the risks associated with draft articles.

Although it covers a fairly technical area of international law, the Guide can be characterized as ambitious. The guide's length (630 pages with commentaries) alone reflects the Commission's striving to be comprehensive. The Guide also does not shy away from addressing what is probably the most controversial issues related to treaty reservations: the competence of human rights bodies to assess the validity of reservations to human rights treaties. (Marko Milanovic and Linos-Alexandre Sicilianos describe what they characterize as the

5 See Cogan, supra note 2 .

6 See Murphy, supra note 1.

${ }^{7}$ Rep. of the Int'l Law Comm'n, 63d Sess., Apr. 26-June 3, July 4-Aug. 12, 2011, UN Doc. A/66/10; GAOR, 66th Sess., Supp. No. 10 (2011). 
Guide's "remarkable compromise." $)$ Finally, the non-treaty format of the Guide allowed the Commission to include a number of recommendations such as: "A reservation should, to the extent possible, indicate the reasons why it is being formulated." Draft treaty texts have no place for such exhortations—and yet if they are followed, such recommendations can improve treaty practice.

Through the Guide, the Commission seeks to amplify its influence by reaching a broader audience than its draft articles typically do. The Guide's avowed purpose is to "provide assistance to practitioners of international law." The Commission describes the Guide as a "toolbox" where practitioners can find answers to various practical questions related to reservations. This is a difference from the Commission's draft articles, but it is one of degree; the intended audience for draft articles also included practitioners. In fact, both states and members of the Commission anticipated ${ }^{9}$ that the draft articles on state responsibility would be influential without becoming a treaty precisely because they would be cited by international judges and arbitrators. Finally, the Commission's decision to label the Guide as non-binding can help to deflect charges of surreptitious legislation. The Guide still blends codification and progressive development: as the Commission explains in the introduction to the Guide, some provisions in the guidelines reflect "rules the customary nature of which is hardly in doubt," while the customary nature of other rules is "open to question." The non-binding label nevertheless makes it harder for those relying on the Guide to simply assume that its provisions reflect customary international law.

And yet, if this year's work program is an indication of how the Commission is reinventing itself, that reinvention remains incomplete. The Commission's embrace of new formats has not been matched by innovations in its working methods. Most importantly, the Commission remains largely sealed off from private actors. There is no established mechanism for private practitioners, civil society organizations, or academics to engage with the Commission or contribute to its work. Some interactions between the Commission and these groups do occur-but their occurrence is idiosyncratic. In 2010, Steve Charnovitz ${ }^{10}$ sought to document the extent to which the Commission consulted civil society organizations. This information proved difficult to come by, but the bottom line was clear: the Commission rarely consulted with civil society organizations.

Input from non-state actors could be especially helpful for the Commission on two issues. First, such input could help the Commission determine how to approach particular topics. For example, the Commission has indicated that it hopes its current work on customary international law (producing a set of conclusions with commentaries) will "serve as a guide to lawyers and judges who are not experts in public international law."11 It is difficult to see how the Commission can hope to achieve this "practical outcome" without consulting a broad cross-section of practitioners. Consider, too, the Commission's work on the protection of the atmosphere. As Sean Murphy describes, the Commission is trying to walk a fine line on this topic. The Commission hopes to avoid imposing on existing treaty regimes and to avoid interfering with political negotiations on climate change, ozone depletion, and transboundary pollution. The Commission would be better positioned to navigate this delicate context by consulting with a broad range of state and IO representatives as well as non-state actors.

Second, when the Commission's output on a particular topic is heavy on progressive development, nonstate actors ought to have an opportunity to comment on the Commission's work before it becomes finalized.

\footnotetext{
${ }^{8}$ Marko Milanovic \& Linos-Alexander Sicilianos, Reservations to Treaties: An Introduction, 24 EuR. J. INT'L L. 1055, 1058 (2013)

9 James Crawford, Special Rapporteur, Fourth Rep. on State Responsibility, Int'l L. Comm'n, UN Doc. A/CN.4/517 (Apr. 2 , 2001).

10 Steve Charnovitz, New Opportunities for Nongovernmental Actors in the International Law Commission (2010).

${ }^{11}$ Rep. of the Int'l Law Comm'n, 65th Sess., May 6-June 7, July 8-Aug. 9, 2013, UN Doc. A/68/10; GAOR, 68th Sess., Supp. No. 10 (2013).
} 
These comments could be particularly useful to the Commission because neither the Commission's membership nor its working methods give it particular advantages when it comes to formulating proposals about how international law ought to develop.

Enlisting the participation of non-state actors could not only improve the quality of the Commission's output, but also amplify the Commission's influence. The Commission could attract the attention of its audience before its work is completed. Individuals and organizations that participate in generating the Commission's work might develop a sense of ownership that would make them more likely to rely on it later. To be sure, the Commission may also find itself the object of more scrutiny and more criticism as well—but hopefully that additional scrutiny and criticism would serve to further improve the Commission's working methods and output.

In sum, Sean Murphy's report on the Commission's sixty-fifth session offers some indications that the Commission is in the process of reinventing itself. But that reinvention will remain incomplete so long as the Commission declines to update its working methods as well as its outputs. 